\title{
Relation between the histology of bronchial carcinoma and hypertrophic pulmonary osteoarthropathy
}

\author{
M. H. Y ACO U B ${ }^{1}$ \\ From the Brompton Hospital and the London Chest Hospital
}

Hypertrophic pulmonary osteoarthropathy was first described by Bamberger (1889) and Marie (1890) in association with chronic pulmonary tuberculosis and empyema. Thompson (1904) was the first to describe osteoarthropathy in association with carcinoma of the bronchus, although Saundby (1889) described a man aged 37 with 'acromegaly' who had thickening of the hands and joints and died after five months; necropsy showed 'a sarcoma of the left lung with caseating pneumonia which could only be coincidental'. Locke (1915) collected 155 cases of pulmonary osteoarthropathy from the literature; of these, nine had tumours of the "lung, pleura, or mediastinum. Bronchial carcinoma is now regarded as the major cause of osteoarthropathy (Craig, 1937 ; Van Hazel, 1940 ; Editorial, 1954 ; Semple and McCluskie, 1955; Leading Article, 1959). According to Coury (1960), pulmonary osteoarthropathy is secondary to intrathoracic malignant tumours in $90 \%$ of cases and to lung cancer in $80 \%$. The reported incidence of osteoarthropathy in cases of carcinoma of the bronchus varies in different series ; Alvarez (1948) put it as high as $48 \%$, Hansen (1952) as $12 \%$, Flavell (1956) as 5 to $10 \%$; in the series of Clagett, McDonald, and Schmidt (1952) it was only $2 \%$. The purpose of this paper is to point out the correlation between osteoarthropathy and the cell type of bronchial carcinoma as well as the incidence of osteoarthropathy in carcinoma of the bronchus.

MATERIAL

The histology of 60 cases of carcinoma of the bronchus associated with osteoarthropathy collected from the case records of patients admitted to the Brompton Hospital, the London Chest Hospital, and St. Bartholomew's Hospital during the last 15 years was studied. The tumours were

1Present address: Brompton Hospital, London, S.W.3 classified into squamous-cell carcinoma, adenocarcinoma, oat-cell carcinoma, and undifferentiated tumours (polygonal-cell carcinoma, largecell undifferentiated tumours). The incidence of osteoarthropathy in 200 consecutive cases of carcinoma of the bronchus of all cell types as well as 200 cases of oat-cell carcinoma was also studied.

\section{RESULTS}

The histology of cases of bronchial carcinoma associated with osteoarthropathy is showh in Table I; $38.4 \%$ of these patients had squamouscell carcinoma, $30 \%$ had adenocarcinoma, and $31.6 \%$ had undifferentiated tumours. The striking feature is that oat-cell carcinoma was not represented in this series.

TABLE I

HISTOI CGY OF CARCINOMA OF THE BRONCHUS ASSOCIATED WITH HYPERTROPHIC PULMONARY OSTEOARTHROPATHY

\begin{tabular}{|c|c|c|}
\hline Histology & No. of Cases & Percentage \\
\hline $\begin{array}{l}\text { Squamous-cell carcinoma } \\
\text { Adenocarcinoma ... } \\
\text { 'Oat-cell carcinoma } \\
\text { Undifferentiated tumour ... }\end{array}$ & $\begin{array}{r}23 \\
18 \\
0 \\
19\end{array}$ & $\begin{array}{l}38 \cdot 4 \\
30 \\
0 \\
31 \cdot 6\end{array}$ \\
\hline
\end{tabular}

The incidence of osteoarthropathy in the 200 cases of carcinoma of the bronchus of all cell types was $4 \%$. In contrast, none of the 200 patients with oat-cell carcinoma had osteoarthropathy. This is statistically significant $(P<0.005)$.

\section{DISCUSSION}

Osteoarthropathy belongs to a group of closely related syndromes known as dysacromelias (Coury, 1960). These include finger clubbing, pulmonary osteoarthropathy, and pachydermatoperiosteitis (Touraine-Solente-Golé syndrome). The term pulmonary osteoarthropathy should only be applied to patients who have clubbing of the fingers and 
joint symptoms, namely, arthralgia, swelling and stiffness affecting mainly the fingers, wrists, ankles, and knees. Apart from joint pains, some patients have deep-seated bone pain which is burning in character and aggravated by dependency of the involved limb. A tender thickening of the distal third of the arms and legs is common. Gynaecomastia and vasomotor disturbances are occasionally present. Subperiosteal new bone formation is considered essential for the diagnosis ; it usually affects the long bones, particularly the radius and ulna $(80 \%)$, tibia and fibula (74 and $80 \%$ respectively), upper phalanges (about $25 \%$ ), and pelvis (6.5\%) (Coury, 1960). In the most advanced cases the clavicles, spines of the scapulae, and vertebrae may become involved (Compere, Adams, and Compere, 1935). Pachydermatoperiosteitis (Touraine, Solente, and Golé, 1935 ; Vogl and Goldfischer, 1962) is an idiopathic hereditary condition which resembles pulmonary osteoarthropathy except for the absence of joint and bone pains and the presence of marked thickening of the skin of the face and forehead.

The difference in the reported incidence of osteoarthropathy in association with carcinoma of the bronchus is probably due to confusion between simple clubbing of the fingers and osteoarthropathy. I believe that the figure reported in the present series is approximately accurate.

The absence of oat-cell carcinoma from the collected cases of carcinoma of the bronchus associated with osteoarthropathy was confirmed by the finding that none of the 200 cases of oat-cell carcinoma studied had osteoarthropathy ; this is difficult to explain. It is not surprising since the pathogenesis of osteoarthropathy remains uncertain ; the theories concerned have recently been discussed (Yacoub, 1965). Experimental and clinical observations suggest that the condition is caused by a reflex mechanism in which the vagus carries the afferent impulses, but the exact stimulus is not known. Oat-cell carcinoma differs from other types of carcinoma of the bronchus in many ways ; for example, it is often associated with hormonal disturbances and electrolyte imbalance (Brown, 1928; Allott and Skelton, 1960 ; Leading Article, 1965). The rapid growth of oat-cell carcinoma is unlikely to be a cause of the failure of development of osteoarthropathy in such cases since osteoarthropathy secondary to bronchial carcinoma usually precedes any pulmonary symptoms (Craig, 1937 ; Van Hazel, 1940 ; Temple and Jaspin, 1948; Poppe, 1947 ; Berg, 1949 ; Fischl, 1950 ; Vogl, Blumenfeld, and Gutner, 1955). Osteoarthropathy can develop in a short time in association with the most rapidly growing secondary tumours in the lung (Barres, Garetta, Quintane, and Jeantet, 1962).

Osteoarthropathy occurs more frequently in association with 'peripheral' than 'central' tumours of the bronchus (Semple and McCluskie, 1955). This does not explain the absence of osteoarthropathy in cases of oat-cell carcinoma ; the latter is peripheral in $50 \%$ of cases (Walter and Pryce, 1955).

\section{SUMMARY}

The histology of 60 cases of bronchial carcinoma associated with osteoarthropathy was studied. None of these patients had oat-cell carcinoma. The incidence of osteoarthropathy in 200 consecutive cases of carcinoma of the bronchus of all cell types was found to be $4 \%$. In contrast, none of 200 patients with oat-cell carcinoma had osteoarthropathy.

I would like to thank the consulting staff of the Brompton Hospital, the London Chest Hospital, and St. Bartholomew's Hospital for allowing me access to the records of patients under their care. I am particularly grateful to Mr. O. S. Tubbs, Mr. J. R. Belcher, Mr. N. R. Barrett, Dr. G. Simon, and Mr. M. Paneth for their encouragement and help.

\section{REFERENCES}

Allott, E. N., and Skelton, M. O. (1960). Increased adrenocortical activity associated with malignant disease. Lancet, 2, 278.

Alvarez, G. H. (1948). Clinica del cancer de pulmon. Rev. Asoc. méd. argent., 62, 690 .

Bamberger, E. (1889). Sitzung der K. K. Ges. der Aerzte in Wien, 8 März 1889. Wien. klin. Wschr., 2, 226.

Barres, J., Garetta, L., Quintane, G., and Jeantet, R. (1962). Exuberant pulmonary hypertrophic osteoarthropathy of rapid development $\mathrm{C}$ after the metastatic spread of osteosarcoma. Bull. Soc. Méd. O milit. France, 56, 77.

Berg, R., Jr. (1949). Arthralgia as a first symptom of pulmonary lesions. Dis. Chest, 16, 483 .

Brown, W. H. (1928). A case of pluriglandular syndrome: 'Diabetes $\supsetneq$ of bearded women'. Lancet, 2, 1022.

Clagett, O.T., McDonald, J. R., and Schmidt, H. W. (1952). Localized fibrous mesothelioma of the pleura. J. thorac. Surg., 24, 213.

Compere, E. L., Adams, W. E., and Compere, C. L. (1935). General-으 ized hypertrophic osteoarthropathy: An experimental and clinical study with report of two cases. Surg. Gynec. Obstet., 61, 312. N

Coury, C. (1960). Hippocratic fingers and hypertrophic osteoarthropathy. A study of 350 cases. Brit. J. Dis. Chest, B4, 202.

Craig, J. W. (1937). Hypertrophic pulmonary osteoarthrcpathy as the first symptom of pulmonary neoplasm. Brit. med. J., 1, 750 .

Editorial (1954). The hand. Ibid., 1, 384.

Fischl, J. R. (1950). Severe hypertrophic pulmonary osteoarthropathy. Report of a case due to carcinoma of the lung with pathy. Report of a case due to carcinoma of the lung
operation and recovery. Amer. J. Roentgenol., 64, 42.

Flavell, G. (1956). Reversal of pulmonary hypertrophic osteoarthropathy by vagotomy. Lancet, 1, 260.

Hansen, J. L. (1952). Bronchial carcinoma presenting as arthralgia." Acta med. scand., Suppl. 266, p. 467.

Leading article (1965). Hormones produced by malignant tumours. Brit. med. J., 1, 4.

(1959). Clubbing of the fingers and osteoarthropathy. Lancet, 2, 390.

Locke, E. A. (1915). Secondary hypertrophic osteo-arthropathy and 2 its relation to simple club-fingers. Arch. intern Med., 15, 659. 
Marie, P. (1890). De l'ostéo-arthropathie hypertrophiante pneumique. Rev. Méd. (Paris), 10, 1.

Poppe, J. K. (1947). The diagnostic significance of clubbed fingers. Dis. Chest, 13, 658 .

Saundby, R. (1889). A case of acromegaly. Illustrated med. News, 2 , 195.

Semple, T., and McCluskie, R. A. (1955). Generalised hypertrophic osteoarthropathy in association with bronchial carcinoma. Brit. osteoarthropathy
med. J., 1, 754 .

Temple, H. L., and Jaspin, G. (1948). Hypertrophic osteoarthropathy. Amer. J. Roentgenol., 60, 232.

Thompson, H. E. S. (1904). Hypertrophic pulmonary osteo-arthropathy. Med-chir. Trans., 87, 85.
Touraine, A., Solente, G., and Golé, L. (1935). Un syndrome ostéodermopathique: La pachydermie plicaturée avec pachypériostose des extrémités. Presse méd., 43, 1820.

Van Hazel, W. (1940). Joint manifestations associated with intrathoracic tumors. J. thorac. Surg., 9, 495.

Vogl, A., Blumenfeld, S., and Gutner, L. B. (1955). Diagnostic significance of pulmonary hypertrophic osteoarthropathy. Amer. J. Med., 18, 51 .

and Goldfischer, S. (1962). Pachydermoperiostosis: primary or idiopathic hypertrophic osteoarthropathy. Ibid., 33, 166.

Walter, J. B., and Pryce, D. M. (1955). The site of origin of lung cancer and its relation to histological type. Thorax, 10, 117.

Yacoub, M. H. (1965). Cervical vagotomy for pulmonary osteoarthropathy. Brit. J. Dis. Chest, 59, 28. 